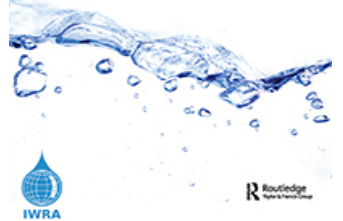

\title{
Transboundary governance in the La Plata River basin: status and prospects
}

\section{Pilar Carolina Villar, Wagner Costa Ribeiro \& Fernanda Mello Sant'Anna}

To cite this article: Pilar Carolina Villar, Wagner Costa Ribeiro \& Fernanda Mello Sant'Anna (2018) Transboundary governance in the La Plata River basin: status and prospects, Water International, 43:7, 978-995, DOI: 10.1080/02508060.2018.1490879

To link to this article: https://doi.org/10.1080/02508060.2018.1490879

曲 Published online: 26 Jul 2018.

Submit your article to this journal $\pi$

Џll Article views: 306

View Crossmark data ¿

Citing articles: 2 View citing articles ๔ 


\title{
Transboundary governance in the La Plata River basin: status and prospects
}

\author{
Pilar Carolina Villar (1D ${ }^{a}$, Wagner Costa Ribeiro ${ }^{b}$ and Fernanda Mello Sant'Anna \\ aDepartment of Marine Sciences, Federal University of São Paulo (UNIFESP), Santos, Brazil; 'bepartment of \\ Political Geography, University of São Paulo, Brazil; 'Department of International Relations, UNESP, Franca, \\ Brazil
}

\begin{abstract}
The La Plata River Basin's transboundary institutional arrangement is a complex system with different geographical bases and scopes, including 14 international organizations, four technical committees and one groundwater commission (not yet implemented). This article examines this institutional architecture by outlining the characteristics of cooperative arrangements established under treaties as a way of analyzing how the process of water governance takes place between riparian states. The large number of institutions contrasts with the modest number of joint actions and projects, which prompts questions about their role in the governance process, especially considering the lack of transparency and information about their performance.
\end{abstract}

\section{ARTICLE HISTORY}

Received 27 July 2017

Accepted 16 June 2018

\section{KEYWORDS}

La Plata River basin; water governance; international cooperation; water organizations

\section{Introduction}

The La Plata River basin (LPRB) is the second-largest drainage basin in South America and the fifth-largest in the world (UNESCO-WWAP, 2006). With an area of around 3.1 million $\mathrm{km}^{2}$, it extends over Argentina, Bolivia, Brazil, Paraguay and Uruguay and can be divided into four main sub-basins: the Paraná, Paraguay, Uruguay and La Plata river systems. The basin also encompasses important transboundary aquifer systems, including the Guarani and Yrenda-Toba-Tarijeño Aquifers, and the Gran Chaco Biome (CIC Plata, 2011).

The strategic relevance of the LPRB area and the use of shared water resources induces both conflict and cooperation initiatives between states. The area has great economic, demographic and environmental significance. It is one of the major producers of electricity and goods in South America and concentrates more than 100 million people (CIC Plata, 2011). Besides this, the project portfolio of South America's Infrastructure and Planning Council (COSIPLAN) includes many joint infrastructural interventions in the area, which may have direct and indirect impacts on the regional water resources (UNASUR \& COSIPLAN, 2016).

The governance of the LPRB poses a number of political, cultural, economic and ecological challenges for the riparian states. Those resources are under the jurisdiction of several states, with power asymmetries, different water policies and distinct levels of 
policy implementation. The main causes of conflicts and cooperation initiatives concerning water resources have been: defining boundaries; navigation; implementation of infrastructure projects; and water use (Sant'Anna \& Villar, 2015). Unlike other transboundary basins in the world, scarcity is not an issue in the LPRB.

Cooperation culminated in the signing of the La Plata Basin Treaty in 1969, establishing for the first time an institutional design for transboundary basin management involving two multilateral organizations and opening the way for the signing of several sub-basin agreements and the creation of new institutions (Caubet, 2006; Gilman, Pochat, \& Dinar, 2008).

The area has been identified as a risk zone for hydro-political tensions or conflicts over the use of water (De Stefano, Petersen-Perlman, Sproles, Eynard, \& Wolf, 2017; Queiroz, 2012; Wolf, Yoffe, \& Giordano, 2003). In the last decade the literature has pointed out several conflicts in the region: the dispute between Brazil and Paraguay over how to share revenue from the Itaipu binational power plant from 2003 to 2010 (Sorgine, 2012); the dispute between Paraguay and Argentina concerning compensation for flooded areas and debt from the construction of the Yacyretá binational power plant (Newman, 2010), which was overcome only by the signing of an agreement 4 May 2017; the conflict between Argentina and Uruguay over pulp mills on the Uruguay River, which started with the implementation of the project in 2005, culminated with the decision of the International Court of Justice in 2010, and restarted in 2013 when Uruguay authorized a higher production capacity (Kaakinen \& Lehtinen, 2016); and social opposition to the Garabi-Panambi project since 2008, when Brazil and Argentina decided to resume the energy project conceived in the 1980s (Saguier, 2018).

Scholars have highlighted the role that joint institutions such as river basin organizations (RBOs) can play in fostering the cooperation of riparian states (De Stefano et al., 2012; Duda \& La Roche, 1997; Green, Cosens, \& Garmestani, 2013; Schmeier, Gerlak, \& Blumstein, 2016; Schmeier, Gerlak, \& Schulze, 2013). ${ }^{1}$ In helping prevent or negotiate conflicts and promote cooperation, these institutions can be positive driving forces for achieving good governance (Schmeier, 2014). However, the extent to which RBOs can be considered key facilitators of good governance has been questioned by some researchers, who have demonstrated problems in their institutional design and performance, as well as limitations on promoting coordination, accountability, legitimacy and effectiveness (Conca, 2006; Lautze, Wegerich, Kazbekov, \& Yakubov, 2013; Morris \& De Loë, 2016; Priscoli \& Wolf, 2009; Schmeier et al., 2016).

This article therefore examines the institutional architecture of water governance in the LPRB by outlining the various cooperative arrangements established by international treaties signed by the five riparian states. The first section focuses on the role that institutions play in promoting water governance and cooperation. The second section goes on to outline the institutional arrangements for the management of the LPRB. The third section explores how these institutions interact with one another in constituting the LPRB transboundary governance system. Finally, conclusions are presented.

We used a four-step methodology to achieve these goals: review of documentary sources in the international water resource management organizations that are active in the LPRB; specialized literature review; interviews with technical staff and managers at these organizations; and compilation and analysis of documents and literature and elaboration of maps and tables. 


\section{Water governance and cooperative institutional arrangements}

'Water governance' has been used as a general concept without any consensus as to its definition (Woodhouse \& Muller, 2017). In its broadest sense, it can be understood as including the 'political, economic and social processes and institutions by which governments, civil society, and the private sector make decisions about how best to use, develop and manage water resources' (UNDP, 2004, p. 10). From a narrower perspective, the term is used to describe 'more or less formal institutions of water governance, their changing characteristics and the roles that they play' (Woodhouse \& Muller, 2017, p. 225).

Transboundary water governance focuses on interstate relations, particularly the formulation of international agreements and creation of joint institutions (Suhardiman \& Giordano, 2012). National governments are undoubtedly key actors, but a state-centred analysis ignores the presence of other actors and does 'not explain how state decision-making develops from or influences intra-national power dynamics, as it tends to overlook the scalar relationships and interactions between regional, national, sub-national, and local' (p. 300).

Sneddon and Fox (2006, p. 182) argued that writers on transboundary river basins 'understand conflicts over water as limited almost exclusively to inter-state conflicts, and thus have very little to say about the multi-scalar, multi-actor character of water politics'. Therefore, it is important to improve studies with a multi-scale and multiactor perspective on water governance in many regions, including the LPRB, as well as to analyze how regional institutions can include this dimension. The pulp mills conflict arose at the local level, but evolved to international dimensions. The tensions over the Garabi-Panambi project might have the same destiny.

A legal agreement cannot solve transboundary water problems by itself. Negotiation is necessary between sovereign states that have different institutions, laws and interests (Ribeiro, 2010; Sant'Anna \& Villar, 2015). Joint institutional arrangements have been established to promote the effective transboundary management of water quality and quantity, energy production and navigation, joint monitoring, information sharing, project and infrastructure development, the creation of warning and alarm systems, and mutual assistance (Vollmer et al., 2008). ${ }^{2}$

International water resource institutions are recognized by scholars, international organizations and states as key actors in preventing conflict and promoting cooperation (Fischhendler, 2008; Hensel, Mitchell, \& Sowers, 2006; Mitchell \& Hensel, 2007; Sant'Anna \& Ribeiro, 2014; Vollmer et al., 2008; Wolf, 2007). There is consensus on the need to develop effective and functional organizations to promote water governance on multiple political scales, including the international level, and as a multi-scalar process that can be approached top-down or bottom-up (Finger, Tamiotti, \& Allouche, 2006; Jaspers \& Gupta, 2014; Schmeier, 2013; Woodhouse \& Muller, 2017).

The organization institutional architecture is influenced by different levels of cooperation, described by Gerlak (2007, pp. 3-4) as shallow cooperation, which occurs 'without official head-quarters or formalized bureaucratic mechanisms of cooperation'; intermediate cooperation, characterized by 'regular meetings between the parties, and a permanent headquarters or secretariat with independent staff, yet without financial independence 
(i.e. donor dependent)'; and deep cooperation, characterized by 'a high degree of bureaucratic organization and financial independence'.

Lautze et al. (2013) demonstrated the diversity of international RBOs in transboundary river basins in terms of their type (committee, commission, authority), treaty and distribution and how these factors impact regulations in the basin. They concluded that some organizations are created for the sole purpose of development, while others balance monitoring and regulation with development. In some developing countries, basin-wide authorities are de facto regulated by 'country-level regulatory institutions and international actors, such as the World Bank and environmental NGOs' (p. 41).

Schmeier (2012) would classify RBOs according to their functions, which should address the collective-action problems for which they were created. According to her, RBOs can deal with a single, few or many themes, such as: basin management and development planning; capacity building; data and information management and exchange; drinking water management; environmental protection; fishery management; flood management; harmonization of national water policies; hydropower management; infrastructure development and operation; invasive species management; investment facilitation and resources mobilization; irrigation management and agricultural development; navigation management; promotion of socio-economic development; research; water allocation; and water pollution control and water quality improvement.

The institutional capacity in a basin is affected by the existence of effective RBOs and treaties (Priscoli \& Wolf, 2009), but other factors also have to be considered, such as the geopolitical relations in the basin (Zeitoun \& Mirumachi, 2008). Since there are different kinds of institutional development of RBOs, good governance and cooperation are not effected by the simple presence of these institutions (De Stefano et al., 2017; Schmeier, 2012; Schmeier et al., 2016).

While some authors highlight the important role played by institutions in fostering cooperation and Integrated Water Resources Management (Saleth, 2004), others warn of the challenges faced in creating and maintaining efficient institutions that actually achieve their purposes and include all the riparian states (Tobias \& Bernauer, 2007). Many of these RBOs do not have vital institutional mechanisms such as data and information sharing arrangements, conflict resolution provisions or participation spaces that extend beyond nation-states (Giordano et al., 2014).

Institutional effectiveness is related to the capacity of organizations 'to perform the task for which it was designed' (Berardo \& Gerlak, 2012). Hearns, Henshaw, and Paisley (2014) describe a five-step process for developing effective institutions: analysis of the basin situation or context; development of appropriate institutional objectives; development of the architectural design of the institutional arrangement; implementation; and monitoring and enforcement.

According to Berardo and Gerlak (2012, pp. 104-05), there are two levels of institutional effectiveness. The first is related to the interstate agreement that structures and shapes the relationships among the parties, including management principles, institutional arrangements and process design. The second can be thought of as process challenges that must be continuously faced to ultimately achieve collaborative solutions to problems in the river basin'. It includes 'transparency in the decision making process', 'production and dissemination of scientific knowledge', 'formal mechanisms for dispute settlement', and 'public participation and representation'. Hearns et al. 
(2014) also include the idea of adaptability, openness and feasibility. Thus, institutional efficiency is related to the constitutional aspects of the organization, such as its powers and parts, as well the ways in contributes to cooperation.

Practice shows that states prefer bilateral cooperation to the inclusion of all riparian countries. Espey and Towfique (2004) explain this preference based on the arguments that bilateral cooperation is easier to achieve and it represents the first step in building multilateral arrangements. They argue that problems related to power asymmetries or distrust between states are easier to manage in bilateral cooperation and also that the position of the state in the river basin (upstream or downstream) influences the type of cooperation.

A UN-WATER report (2008, p. 6) indicates that around 158 of the world's 263 transboundary river basins do not have 'any type of cooperative management framework', which in turn compromises the governance of water resources. Although institutional architecture is not a panacea (Bernauer, 1997; Dombrowksy, 2008; Hearns et al., 2014), it is seen as an important step towards transboundary water cooperation and governance. As Hearns et al. (2014, p. 10) state, 'you can't always get what you want' when it comes to cooperative water regimes in transboundary basins.

The role of institutional arrangements is directly determined by the nature of cooperation. Performance is affected by the organization of national and international basin actors and can also be influenced by external forces, such as international organizations that provide expertise or funding and international nongovernmental organizations. International cooperation is an open and nonlinear process (O'Neill, Balsiger, \& Van Deveer, 2004). Thus, the performance of institutions can face setbacks or stagnation according the type of relations between countries, the availability of funding, and social pressure on water resources.

Building and maintaining effective institutional arrangements for water resources management is a major challenge for countries. Negotiations over the joint use of water demand the engagement of public and private stakeholders. Involving subnational actors in the cooperation process is a challenge for transboundary water institutions, since generally their statutes do not envisage this type of participation. These types of institutional arrangements therefore generally ignore the local level, resulting in institutions and agreements that are not recognized by water users.

The experience of the LPRB shows that complex institutional designs do not necessarily ensure effective cooperation or the good governance of transboundary waters and demonstrates the need for improved coordination and greater transparency among institutions (Sant'Anna \& Villar, 2015).

\section{Institutional cooperative arrangements in the La Plata River basin}

The first conflicts and cooperation initiatives related to La Plata basin rivers go back to the definition of the boundaries between countries. To resolve boundary disputes, states established joint limits commissions as a way of negotiating boundaries in controversial areas. ${ }^{3}$ After the Second World War, states started to consider rivers beyond their borders and signed several treaties to promote the joint use of waters, especially for navigation and energy production (Gilman et al., 2008; Sant'Anna \& Villar, 2015). 
The LPRB institutional framework started to take shape in the 1960s with the creation of the Intergovernmental Coordinating Committee for the La Plata Basin Countries (CIC, acronym in Spanish) and the signing of the La Plata Basin Treaty. This agreement was stimulated by the states' desire to exploit the rivers' hydropower potential (Caubet, 1991) and was the first step towards forming a complex system of cooperative arrangements.

The La Plata Basin Treaty, signed in 1969, was a milestone in that it formally institutionalized international cooperation between the countries for the utilization of water resources, adopted the concept of river basin, and served as a basis for agreements concerning sub-basins (Laborde, 2008). The treaty introduced a system of governance anchored in the Meeting of Chancellors of the Countries of the Plata Basin, the CIC and its General Secretary; and established a funding mechanism called the Financial Fund for the Development of the La Plata Basin (FONPLATA, acronym in Spanish) (Caubet, 1991). ${ }^{5}$

The CIC was created as a permanent body 'that promotes, coordinates and conducts multinational actions aimed at promoting the better use of the resources of the La Plata River Basin and harmonious and balanced regional development, to achieve the objectives' of the treaty and 'the execution of the Resolutions of the Meeting of Chancellors' (Article 1 of the CIC Statute). Although the statute assigned a strategic role to the body, its performance was affected by each state's vision of sovereignty over water resources and the overlapping arrangements in the sub-basins.

Although the CIC comprised all countries, Article 6 of the La Plata Basin Treaty encouraged 'specific or partial bilateral or multilateral agreements, directed at the fulfilment of the general development goals for the basin'. This article allowed the creation of a complex institutional architecture comprising a range of cooperative institutional arrangements for managing water resources.

The creation of multiple organizations was boosted by the position of the states in relation to sovereignty over rivers. The fourth Meeting of Chancellors of the Countries of the La Plata Basin approved Resolution 25, known as the Declaration of Asuncion on the Use of International Rivers (CIC, 1971), which provided for joint sovereignty over contiguous rivers and established the need for bilateral agreements between riparian states to govern the use of water resources. On the other hand, successive rivers would not be subject to the principle of joint sovereignty, and therefore states would be free to exploit their water resources as long as they did not cause significant harm to other states $^{6}$ (Caubet, 2006).

Although the scope of the La Plata Basin Treaty was the water basin, cooperation between countries focused on the contiguous rivers that constitute borders between two or more countries. This can be explained by the strategic significance of border areas and water resources: rivers are not static lines, and water has multiple uses; and since states do not have full sovereignty over these areas, they seek ways of securing their borders and guaranteeing water and related activities. On the other hand, successive rivers flow within the territory of a particular country, but cross its border and continue flowing through the territory of another country. Since they do not constitute a boundary, states are less motivated to enter into agreements that could limit their sovereignty over these resources.

Overall, six types of organizations can be identified in the LPRB: 
(1) International organization for river basin management and development: these are organizations that have legal personality under international law and aim to propose and develop actions, projects and studies identified by member states as being necessary for the use of water resources and basin management or development. $^{7}$

(2) International organization for river stretch development: these are organizations that have legal personality under international law and aim to propose and develop actions, projects and studies identified by member states as being necessary for the use of the water resources of a specific stretch of a regional river.

(3) International funding organization: an organization that has legal personality under international law aimed at funding studies, projects, programmes and works that promote the development and regional integration of the basin.

(4) International organization dedicated to improving navigation: an international organization dedicated to promoting projects, studies, regulations and works that improve navigation on regional rivers.

(5) International organization for the operation of energy projects: these are binational organizations that jointly administer hydroelectric power plants located on contiguous rivers.

(6) Technical committees for developing joint projects and actions: support bodies, without legal personality under international law, aimed at enabling technical cooperation on matters of interest to the countries. To this end, they promote programmes, projects, studies, construction works, maintenance, operations and other related activities around a common purpose, such as development of energy potential studies, improvement of navigation conditions, and environmental protection analysis.

Table 1 synthesizes the cooperative institutional arrangements established by international treaties to address issues related to the management of the LPRB's water resources. There are 19 organizations involved in the management of the basin's water resources, though one is not yet functional (the Guarani Aquifer Commission - for more information see Villar and Ribeiro (2011); Villar (2016). Cooperation takes place at different scales, ranging from the entire river basin to sub-basins, individual rivers and stretchers of rivers. Two organizations, the CIC and FONPLATA (see the table for abbreviations used in this section), encompass the entire LPRB and include representatives from each of the five riparian states. Five organizations address specific sub-basins: the CRA (the Apa River basin); COBINABE (the Upper Bermejo and Grand Tarija River basin); BACLRPB and TCDPRB (the Pilcomayo River basin); and the CRQ (the Quaraí River basin). But most of the organizations are responsible for the utilization of stretches of contiguous rivers (COMIP and CCDFR, Itaipu, Yacyretá, JTECPR, CARP, CARU, Salto Grande, CC and JTC). Only one organization is responsible for the utilization of successive rivers: the $\mathrm{CIH}$, which governs the navigation of the Parana and Paraguay Rivers, encompassing all the riparian countries.

The majority of the organizations have legal personality under international law, ${ }^{8}$ except for the CCDFR, JTECPR, CC and JTC, which are technical bodies linked to national or international institutions. Despite the existence of a specific international 


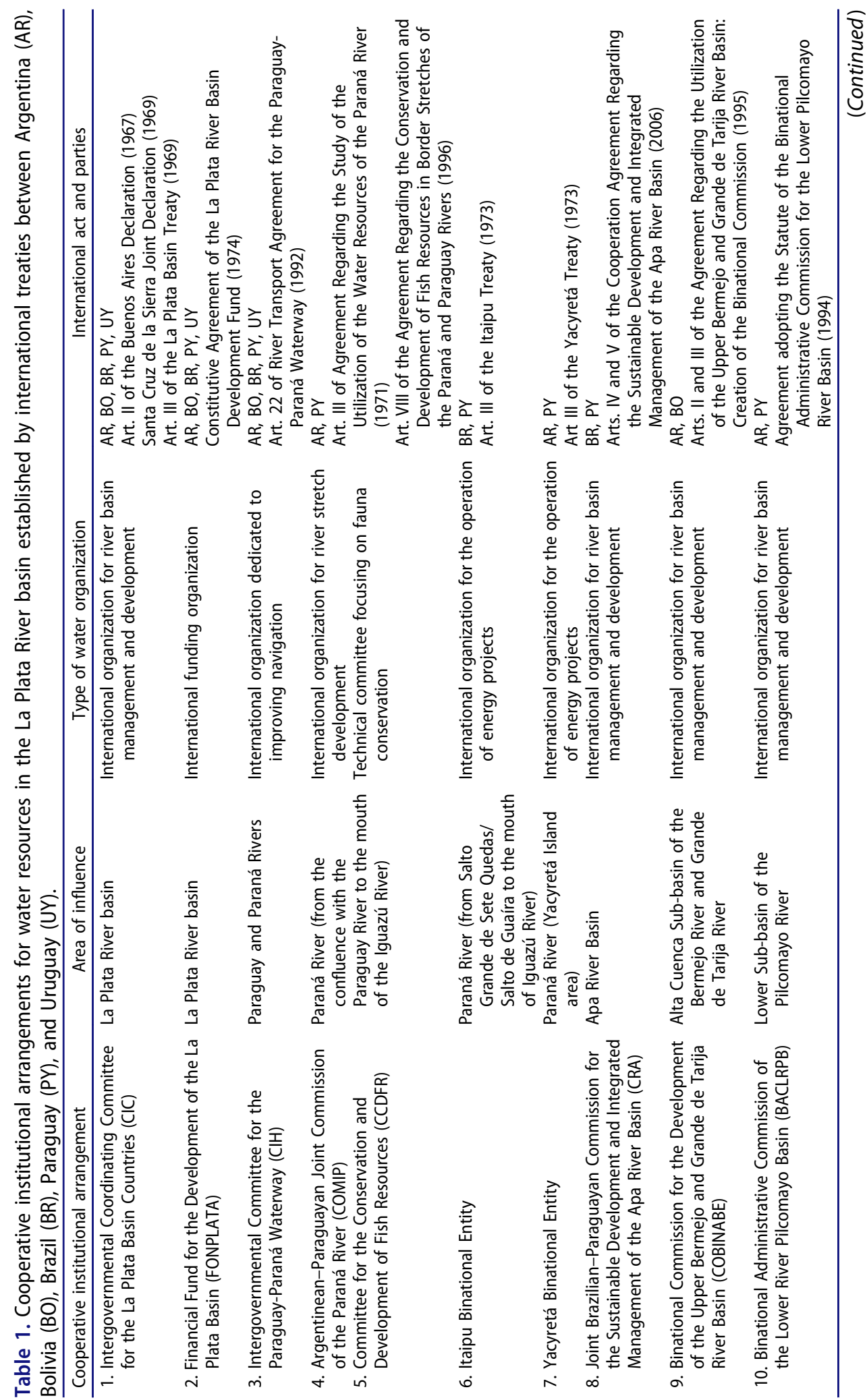




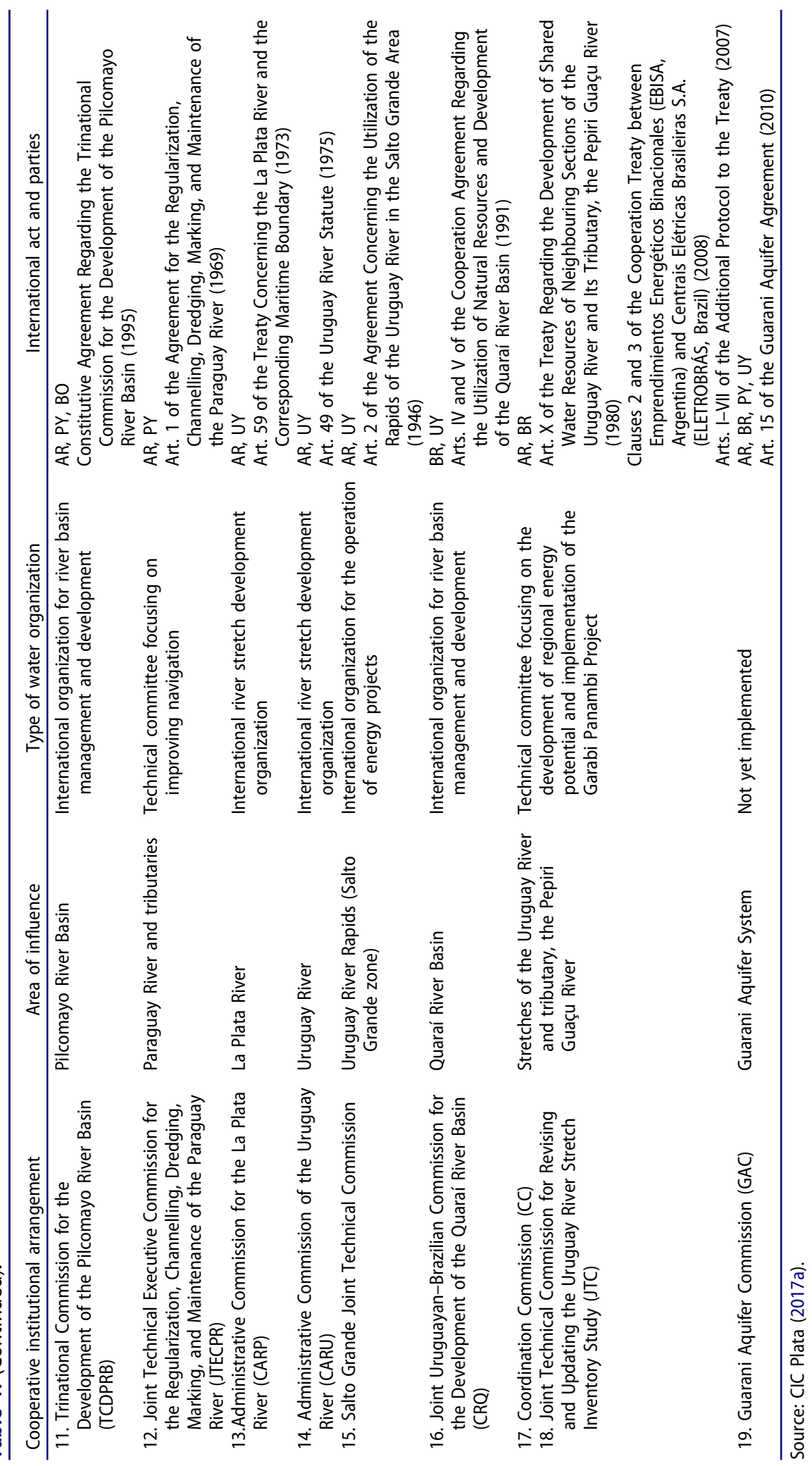


organization to promote the development of the entire LPRB, the countries decided to create new organizations dedicated to specific parts of the river basin and the management of specific projects. This profusion of different organizations for the management of a single area requires careful planning to ensure the effective implementation of Integrated Water Resources Management.

\section{Building a governance process on the international institutional arrangements set up to manage the La Plata River basin}

The institutional arrangements for promoting water cooperation in the LPRB are fairly well developed, but not flawless. There are 14 organizations with legal personality under international law acting on the Plata Basin territory. Despite those organizations having different purposes, cases of overlapping competences can be identified. Figure 1 shows the areas under the jurisdiction of these organizations.

Three organizations encompass all five countries: the CIC, which generated the multilateral governance process; FONPLATA, whose focus is project funding; and the CIH, which aims to promote navigation, a common interest shared by the riparian states. Also, there are one trinational and ten binational organizations with international personality that coexist with these regional organizations. The Paraguay River is a good example of the coexistence of regional and bilateral organizations. In the Paraguay sub-basin, we identify

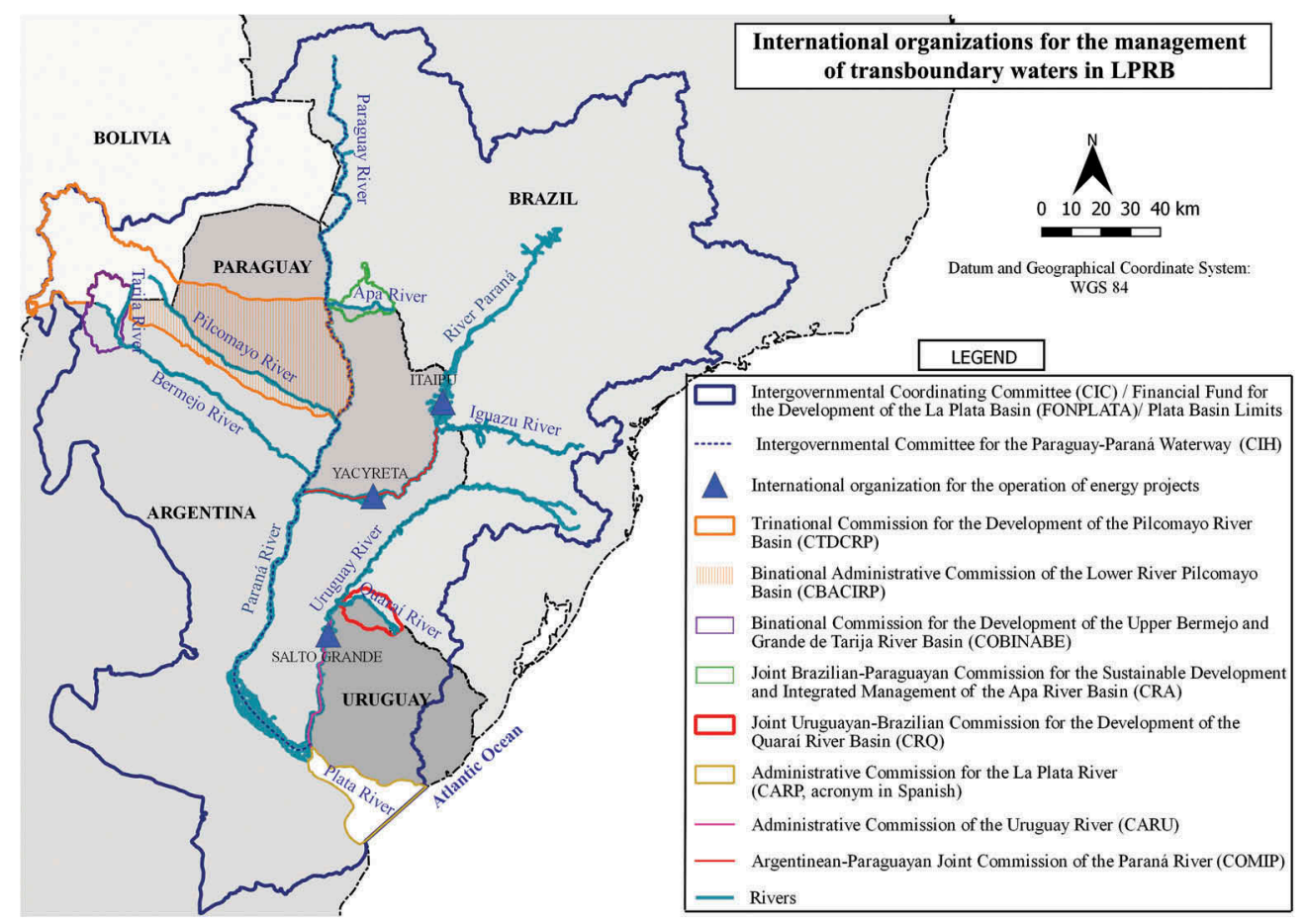

Figure 1. International organizations for the management of shared water resources in the La Plata River basin. 
the influence of eight organizations: the three organizations that encompass all the riparian states, one trinational organization, and four binational organizations.

In the Paraná River basin, international organizations for the operation of energy projects (Itaipu and Yacyretá) play a predominant role in the use of the water resources. Yacyretá's area of the river is also under the competence of the Joint ParaguayanArgentine Commission for the Paraná River (COMIP), so those organizations should encourage common initiatives, since they both have powers over the river.

Three bilateral organizations are responsible for the management of the Uruguay River, each with the participation of Uruguay. Two include the participation of Argentina: one aimed at promoting the joint development of a shared stretch of the Uruguay River (CARU) and one dealing with the operation of a hydroelectric project (Salto Grande). CARU and Salto Grande also carry out overlapping activities, since both have powers over the river. The third, the CRQ, is an international organization that aims to promote the development of the Quaraí River basin; the Quaraí is a tributary of the Uruguay River.

There is also an overlap of activities in the Paraguay sub-basin. BACLRPB is responsible for the Lower Pilcomayo River basin, while the TCDPRB is responsible for the whole basin. Despite this clear overlap, no agreement exists between these two commissions. The management of these areas is also influenced by the activities of the $\mathrm{CIH}$.

Table 2 shows the organizations in the four main regional sub-basins: the Paraguay, Paraná, La Plata, and Uruguay. These overlapping jurisdictions demand greater coordination between the various organizations that make up the institutional arrangements for the management of the LPRB. In this, the CIC plays a key role, since it is the only organization that has the power to promote cooperation across the whole river basin. However, the CIC's contribution as a driver of cooperation remains timid.

Only five agreements have been signed between those organizations. Four were between international basin or river organizations to promote the development of environmental projects with international funding; one was between two international organizations for the operation of energy projects concerning technical cooperation 9 :

Table 2. Organizations with international personality and jurisdiction over the main sub-basins of the La Plata River Basin (for full names, see Table 1).

\begin{tabular}{ll}
\hline Sub-basin & Organizations subject to overlapping jurisdictions \\
\hline Paraguay River & CIC and FONPLATA \\
& CIH \\
& COMIP \\
& CRA \\
& BACLRPB \\
& TCDPRB \\
& COBINABE \\
& CIC and FONPLATA \\
Parana River & CIH \\
& ITAIPU \\
& YACYRETA \\
La Plata River & CIC and FONPLATA \\
& CARP \\
Uruguay River & CIC and FONPLATA \\
& SALTO GRANDE \\
& CARU \\
& CRQ \\
\hline
\end{tabular}


(1) Technical Collaboration and Assistance Framework Agreement between the CIC and CARP (9 August 2004) concerning the execution of the project Environmental Protection of the La Plata River and its Maritime Front: Pollution Prevention and Control and Habitat Restoration, with support from the United Nations Development Programme and the Global Environmental Facility.

(2) Agreement between CARU and CIC (23 March 2005), aimed at promoting technical cooperation for joint projects on the Uruguay River as part of the Programme for the Sustainable Development of the Water Resources of the La Plata River Basin, with the participation of the CIC and the Global Environmental Facility.

(3) Framework Agreement of Understanding and Collaboration between COBINABE and the CIC (1 June 2005) as part of the Strategic Action Programme for the Bermejo Binational River Basin, which received funding from the Global Environmental Facility and support from the United Nations Environment Programme and the Organization of American States.

(4) Interinstitutional Cooperation Framework Agreement between the CIC and the Integrated Management Project and Pilcomayo River Basin Master Plan (agreement between TCDPRB and the European Community), 9 December 2005.

(5) Cooperation Framework Agreement between Itaipu and Yacyretá (10 August 2010), aimed at promoting technical cooperation and mutual support.

Cooperation is not limited to formal agreements, but those legal instruments demonstrate the organizations' intention to institutionalize the process and ensure the powers, obligations and rights of the parties. The states sought to formalize the cooperation process in the 2000s given their interest in implementing the Framework Programme for the Sustainable Management of La Plata River Basin's Water Resources with Respect to the Effects of Climate Variability and Change, whose first phase ended in 2016 (CIC Plata, 2017b).

The Framework Programme was an ambitious cooperation effort since it involved undertaking a macro survey of the whole river basin. According to professionals engaged in the project interviewed during a technical visit to the CIC in 2016, the project included other international organizations working in the river basin. However, it is very difficult to measure the level of interinstitutional interaction, since the final reports do not contain such information and it was not possible to ascertain the type of interaction from the interviews (CIC Plata, 2017b). In addition to promoting knowledge of the basin, this programme created a Decision-Making Support System for the La Plata River Basin (http://sstd.cicplata.org/sstd/), which will make the information produced available to the public. In general terms, the type of cooperation fostered by these organizations focuses on the production of information and technical data.

The agreements signed by the CIC and other basin and river management and development organizations resulted from the execution of specific projects, funded mainly by international organizations, rather than an institutional practice of collaboration between organizations or states. This type of strategy is risky, because with the end of the project and resources, there is no continuity of cooperation (Sant'Anna \& Villar, 2015). Besides the Framework Programme, other projects and programmes have been executed using international funding in the Bermejo River basin, the Brazilian portion 
of the Upper Paraguay River basin, the La Plata River and its Maritime Front, the Guarani Aquifer, and the Gran Chaco Biome (CIC Plata, 2011). Although these projects and programmes contributed to promoting the production of technical information on the region, they failed to promote formal institutional actions.

For example, the Guarani Aquifer System Project contributed to the signing of the Guarani Aquifer Agreement. However, the ratification process has been a long process, holding back the implementation of what would have been the only transnational institution dedicated to transboundary groundwater resources in South America (Villar, 2016). Only in 2017 did Brazil accept the agreement with the issue of Legislative Decree 52/2017. ${ }^{10}$ Paraguay has rethought its refusal of the agreement and ratified it with the approval of Act 6037/2018. ${ }^{11}$ After almost eight years, the four countries have ratified the agreement, which 'shall enter into force on the thirtieth day following the date of deposit of the fourth instrument of ratification' (Article 21).

Funding is a particularly sensitive issue in the region. In general terms, organizations that promote the development of basins and rivers face a number of challenges related to lack of financial and technical resources. They depend heavily on government funding and are in turn affected by shortfalls and untimely disbursement, thus increasing their dependence on external funds for the execution of projects. The CIC, the oldest of the organizations, reports problems of this nature. ${ }^{12}$ Cooperation is therefore subject to the availability of resources and goes through periods of progress and stagnation. With the end of the first phase of the Framework Programme, the CIC remains heavily dependent on its capacity to seek external funds to ensure the continuity of the cooperation process.

Although FONPLATA has contributed to the development of projects involving the management of transboundary resources, its main focus is construction works. Although areas such as the environment and water resources are included, the fund gives priority to national physical infrastructure, particularly road infrastructure (FONPLATA, 2015). But the fund has financed environmental projects in the Bermejo, Tarija, and Paraguay River basins and in the Uruguay River, as well as investing in navigation improvement works (FONPLATA, 2015).

The Itaipu and Yacyretá agreements established a cooperation initiative that encourages the exchange of information and capacity building. In addition, Yacyretá and Salto Grande decided to adopt the Cultivating Good Water programme (http://www.cultivandoaguaboa. com.br/) developed by Itaipu. The CIC facilitated coordination and communication among the three institutions during this process.

Regarding the Uruguay River, it is also important to mention the informal cooperation between CARU and Salto Grande involving monitoring of the fish population in the dam (CARU \& Comisión Técnica Mixta Salto Grande, 1997) and meetings to implement joint monitoring in the region (CARU, 2016). Although CARU failed to effectively negotiate the pulp mills dispute mentioned earlier, the organization was strengthened by an agreement between Argentina and Uruguay that provided for the creation of a technical committee to monitor the Uruguay River as a subsidiary body of the organization (CARU, 2016).

Another limitation of these organizations is the lack of transparency and public participation. Their members include representatives of the Ministries of Foreign Affairs and government staff. They do not provide the opportunity for public participation; meetings are closed to the public, and there is a lack of information on their activities. 


\section{Conclusions}

The institutional arrangements for the management of the LPRB constitute a complex institutional system made up of 14 organizations that have legal personality under international law. The transboundary cooperation system is organized into five different territorial bases that include the entire basin, sub-basins, rivers, river sections and dams.

These organizations have distinct objectives, which include basin, sub-basin or river stretch development, funding programmes or projects, navigation, and the operation of energy projects. In addition, there are four technical committees, which do not have legal personality under international law and are dedicated to gathering information on matters of common interest to the countries (feasibility of hydroelectric projects, navigation improvements, and protection of aquatic fauna). Moreover, a proposal to create a groundwater commission has been tabled, but it depends on the Guarani Aquifer Agreement entering into force.

The lack of transparency and information on the organizations' performance in fulfilling their objectives shows institutional fragility and coordination problems. The simple presence of these organizations does not ensure good governance of the region's transboundary water resources. In fact, the large number of institutions contrasts with the modest number of joint actions or products. The states have not managed to achieve transboundary integrated management of water resources. This makes it necessary to question the status and role of those institutions in a context of multi-scale governance of natural resources.

Most of the agreements between LPRB organizations have been the result of international projects implemented jointly by countries, organizations from the United Nations System, and the Global Environmental Facility. Despite the agreements, there is no evidence of real integration between these organizations, which have failed to conduct systematic cooperation based on the results of these projects or on the priority issues identified by the basin stakeholders. The exceptions are the international organizations responsible for the operation of energy projects, which have reached their goals and targets, though they have not avoided conflicts.

In light of these points, and considering the fragility of the institutional arrangements put in place to manage the basin, significant challenges remain to be addressed to ensure the resolution of eventual conflicts and stimulate transboundary water governance. It is therefore vital to take measures to improve institutional capacity and promote effective coordination among these organizations.

\section{Funding}

This research was funded by Fundação de Amparo à Pesquisa do Estado de São Paulo [Processo FAPESP no. 2014/21734-5] and Conselho Nacional de Desenvolvimento Científico e Tecnológico (CNPq) [Processo CNPq no. 310631/2014-9].

\section{Notes}

1. Acta de Entendimiento entre la Republica del Paraguay y la Republica de la Argentina (http://www.lanacion.com.py/politica/2017/05/04/paraguay-firma-con-argentina-histor ico-acuerdo-sobre-yacyreta/). This agreement reviewed Annex C of the Yacyretá Agreement. 
2. RBOs can be defined as 'institutionalized forms of cooperation that are based on binding international agreements covering the geographically defined area of international river or lake basins characterized by principles, norms, rules and governance mechanisms' (Schmeier et al., 2013, p. 8).

3. For more information, see the International Freshwater Treaties Database (http://trans boundarywaters.science.oregonstate.edu/content/international-freshwater-treatiesdatabase).

4. For example, the Joint Paraguayan-Argentine Border Commission (Comisión Mixta de Fronteiras Argentino-Paraguaya) to define the borders of the Pilcomayo River and the Joint Inspection Commission of the Landmarks of the Brazil-Argentina Border of the Pepiri Guassu River (Comissão Mista de Inspeção dos Marcos da Fronteira BrasilArgentina no Pepiri Guassu).

5. The CIC was created before the signing of the La Plata Basin Treaty through a joint declaration signed by state representatives at the First Meeting of Ministers of Foreign Affairs of the Countries of the La Plata Basin, in Buenos Aires, Argentina, 27 February 1967. Its original statute and the headquarters agreement were approved in 1968 and 1973, respectively.

6. The terms contiguous and successive rivers refer to watercourses that form or traverse boundaries between states. Rivers bordering the territories of two or more states are termed contiguous rivers or boundary rivers. Rivers passing through the territories of two or more states are termed successive.

7. FONPLATA is the treaty's financial body. Its objective is 'to conduct studies, projects, programmes and works to promote the harmonious development and physical integration of the La Plata Basin'.

8. The meaning of the word 'development' in this typology is based on the nomenclature adopted by the treaties signed by the countries; thus, it does not amount to a qualitative analysis of the type of development proposed.

9. Organizations must meet five requirements to be granted legal personality under international law: this type of personality is deemed necessary for the performance of its functions; it has its own bodies with specifically defined tasks; the organization's constitutive instrument establishes obligations of members as regards the organization; its legal capacity, privileges and immunities in the territory are recognized; and agreements between the organization and its members have already been established or will be made in the foreseeable future (Zeballos, 1979).

10. The former website of the CIC also mentioned an agreement between CIC and Itaipu. According to Itaipu, this agreement was not legally formalized, but Itaipu made a transfer of funds to hire services and buy equipment for CIC.

11. Legislative Decree 52/2017 (3 May 2017) approves the text of the Guarani Aquifer Agreement, signed in San Juan, Republic of Argentina, 2 August 2010 (http://www2. camara.leg.br/legin/fed/decleg/2017/decretolegislativo-52-3-maio-2017-784714-acordo152560-pl.html).

12. Act 6037/2018 (17 April 2018) approves the Guarani Aquifer Agreement (http://www. gacetaoficial.gov.py/index/detalle_publicacion/54350).

13. Information obtained from interviews with CIC staff, Buenos Aires, August 2016.

\section{ORCID}

Pilar Carolina Villar (1D http://orcid.org/0000-0002-7222-1609

Fernanda Mello Sant'Anna (D) http://orcid.org/0000-0003-1163-0588 


\section{References}

Berardo, R., \& Gerlak, A. K. (2012). Conflict and cooperation along international rivers: Crafting a model of institutional effectiveness. Glob. Environ. Politics, 12(1), 101-120.

Bernauer, T. (1997). Managing international rivers. In O. R. Young (Ed.), Global governance: Drawing insights from the environmental experience (pp. 155-195). Cambridge, MA: MIT Press.

CARU (2016). Delegados de CARU delinearon trabajos en conjunto con CTM-SG [CARU delegates outlined joint work with CTM-SG]. Retrieved from http://www.caru.org.uy/web/ 2016/07/delegados-de-caru-delinearon-trabajos-en-conjunto-con-ctm/

CARU \& Comisión Técnica Mixta Salto Grande (1997). Conservación de la Fauna íctica en el Embalse de Salto Grande. Retrieved from: http://www.caru.org.ar/web/pdfs_publicaciones/ Conservacion-de-la-fauna-iticola-en-el-embalse-de-Salto-Grande.pdf.

Caubet, C. G. (1991). As grandes manobras de Itaipu: Energia, diplomacia e direito na Bacia do Prata [The great maneuvers of Itaipu: Energy, diplomacy and law in the Prata Basin]. São Paulo: Editora Acadêmica.

Caubet, C. G. (2006). A água doce nas relações internacionais [Fresh water in international relations]. Barueri: Manole.

CIC Plata (Comité Intergubernamental Coordinador de los Países de la Cuenca del Plata). (1971). Resolución no 25 de la IV Reunión de Cancilleres de los países de la Cuenca del Plata. declaración de Asunción sobre aprovechamiento de ríos internacionales. Asunción, Paraguay: CIC Plata, 3 June, 1971.

CIC Plata. (2011). Programa para a gestão sustentável dos recursos hídricos da Bacia do Prata, considerando os efeitos decorrentes da variabilidade e mudança do clima. Buenos Aires: CIC Plata.

CIC Plata (2017a). Marco institucional y legal para la gestión integrada de los recursos hídricos en la Cuenca del Plata [Institutional and legal framework for the integrated management of water resources in the River Plata Basin]. Estados Unidos: OEA. Retrieved from http://cicplata. org/wp-content/uploads/2017/04/marco_institucional_y_legal_20170424.pdf

CIC Plata (2017b). The framework program for the sustainable management of La Plata Basin's water Resources, with respect to the effects of climate variability and change. Strategic action program for the La Plata Basin. 2017 Estados Unidos: OEA.

Conca, K. (2006). Governing water: Contentious transnational politics and global institution building. Cambridge: MIT Press.

De Stefano, L., Duncan, J., Dinar, J., Stahl, K., Strzepek, K. M., \& Wolf, A. T. (2012). Climate change and the institutional resilience of international river basins. Journal of Peace Research, 49(1), 193-209.

De Stefano, L., Petersen-Perlman, J. D., Sproles, E. A., Eynard, J., \& Wolf, A. T. (2017). Assessment of transboundary river basins for potential hydro-political tensions. Global Environmental Change, 45, 35-46.

Dombrowksy, I. (2008). Institutional design and regime effectiveness in transboundary river management - The Elbe water quality regime. Hydrol Earth Systems, 12, 223-238.

Duda, A. M., \& La Roche, D. (1997). Sustainable development of international waters and their basins: Implementing the GEF operational strategy. International Journal of Water Resources Development, 13(3), 383-401.

Espey, M., \& Towfique, B. (2004). International bilateral water treaty formation. Water Resources Research, 40(W05S05), 1-8.

Finger, M., Tamiotti, L., \& Allouche, J. (2006). The multi-governance of water: Four case studies. Albany: State University of New York Press.

Fischhendler, I. (2008). Ambiguity in transboundary environmental dispute resolution: The Israeli-Jordanian water agreement. Journal of Peace Research, 45(1), 91-109.

FONPLATA, 2015. Relatório e demonstrações financeiras [Report and Financial Statements]. Retrieved from http://www.fonplata.org/memoria-anual-2015.html. 
Gerlak, A. K. (2007, February). Regional water governance and institutional arrangements around transboundary waters. Chicago, IL: Paper presented at the annual meeting of the International Studies Association 48 th Annual Convention.

Gilman, P., Pochat, V., \& Dinar, A. (2008). Whither La Plata? Assessing the state of transboundary water resource cooperation in the basin. Natural Resources Forum, 32(3), 203-214.

Giordano, M., Drieschova, A., Duncan, J. A., Sayama, Y., De Stefano, L., \& Wolf, A. T. (2014). A review of the evolution and state of transboundary freshwater treaties. International Environmental Agreements: Politics, Law and Economics, 14(3), 245-264.

Green, O. O., Cosens, B. A., \& Garmestani, A. S. (2013). Resilience in transboundary water governance: The Okavango River Basin. Ecology and Society, 18(2), 1-16.

Hearns, G. S., Henshaw, T. W., \& Paisley, R. K. (2014). Getting what you need: Designing institutional architecture for effective governance of international waters. Environmental Development, 11, 98-111.

Hensel, P. R., Mitchell, S. M., \& Sowers, T. E. (2006). Conflict management of riparian disputes. Political Geography, 25(4), 383-411.

Jaspers, F., \& Gupta, J. (2014). Global water governance and river basin organizations. In D. Huitema \& S. Meijerink (eds), The politics of River Basin organizations: coalitions, institutional design choices and consequences (pp. 38-66). Cheltenham (UK): Edward Elgar.

Kaakinen, I., \& Lehtinen, A. (2016). A bridge that disconnects - On shared and divided sociospatialities in the pulp mill conflict between Uruguay and Argentina. Forest Policy and Economics, 7, 106-112.

Laborde, L. C. (2008). The Rio de la Plata River Basin: The path towards Basin institutions. In O. Varis, C. Tortajada, \& A. K. Biswas (Eds.), Management of transboundary Rivers and Lakes (pp. 269-289). Verlag Berlin Heidelberg: Springer.

Lautze, J., Wegerich, K., Kazbekov, J., \& Yakubov, M. (2013). International river basin organizations: Variation, options and insights. Water International, 38(1), 30-42.

Mitchell, S. M., \& Hensel, P. R. (2007). International institutions and compliance with agreements. American Journal of Political Science, 51(4), 721-737.

Morris, M., \& De Loë, R. C. (2016). Cooperative and adaptive transboundary water governance in Canada's Mackenzie River Basin: Status and prospects. Ecology and Society, 21(1), 1-13.

Newman, S. J. (2010). Capitalist development as white elephant: A case study of Argentina's Yacyretá Hydroelectric Dam. Eleven: the Undergraduate Journal of Sociology, 1, 54-83.

O'Neill, K., Balsiger, J., \& Van Deveer, S. D. (2004). Actors, norms, and impact: Recent international cooperation theory and the influence of the agent structure debate. Annual Review of Political Science, 7, 149-175.

Priscoli, J. D., \& Wolf, A. T. (2009). Managing and Transforming Water Conflicts. Cambridge: Cambridge University Press.

Queiroz, F. A. (2012). Hidropolítica e segurança: As bacias platina e amazônica em perspectiva comparada [Hidropolitics and security: The Plata and Amazon River Basins in a comparative perspective] (pp. 1-411). Brasilia: FUNAG.

Ribeiro, W. C. (2010). Political Geography and international management of natural resources. Estudos Avançados, 24(68), 69-80.

Saguier, M. (2018). Transboundary water governance in South America. In P. Riggirozzi, \& C. Wylde (Eds.), Handbook of South American Governance (pp. 125-145). New York: Rouledge.

Saleth, R. M. (2004). Introduction to special section on river basin management: Economics, management, and policy. Water Resources Research, 40(W08S01), 1-6.

Sant'Anna, F. M., \& Ribeiro, W. C. (2014). Water security and interstate conflict and cooperation. Documents d'Anàlisi Geogràfica, 60, 573-596.

Sant'Anna, F. M., \& Villar, P. C. (2015). Gobernanza de las aguas transfronterizas: Fragilidades institucionales en América del Sur. America Latina Hoy, 69, 53-74.

Schmeier, S. (2012). Navigating cooperation beyond the absence of conflict: Mapping determinants for the effectiveness of river Basin organizations. International Journal for Sustainable Societies, 4(1-2), 11-27. 
Schmeier, S. (2013). Governing international watercourses: River basin organizations and the sustainable governance of internationally shared rivers and lakes. London, UK: Routledge.

Schmeier, S. (2014). The institutional design of river basin organizations - Empirical findings from around the world. International Journal of River Basin Management, 13, 51-72.

Schmeier, S., Gerlak, A. K., \& Blumstein, S. (2016). Clearing the muddy waters of the shared watercourses governance: Conceptualizing international river Basin organizations. International Environmental Agreements: Politics, Law and Economics, 16, 597.

Schmeier, S., Gerlak, A. K., \& Schulze, S. (2013). Who governs internationally shared watercourses? Clearing the muddy waters of international river Basin organizations. Lund and Amsteran: Earth System Governance.

Sneddon, C., \& Fox, C. (2006). Rethinking transboundary waters: A critical hydropolitics of the Mekong basin. Political Geography, 25(20), 181-202.

Sorgine, G. (2012). O caso Itaipu: Estratégias e legitimação nas relações Brasil - Paraguai [The case of Itaipu: Strategies and legitimation on Brazil and Paraguay relations]. Conjuntura Internacional, 9(5), 41-49.

Suhardiman, D., \& Giordano, M. (2012). Process-focused analysis in transboundary water governance research. International Environmental Agreements: Politics, Law and Economics, 12(3), 299-308.

Tobias, S., \& Bernauer, T. (2007). Estimating the performance of international regulatory regimes: Methodology and empirical application to international water management in the Naryn/Syr Darya Basin. Water Resources Research, 43(W11406), 1-14.

UNASUR \& COSIPLAN. Cartera de Proyectos 2016. COSIPLAN, 2016. Retrieved from: https:// www.flipsnack.com/IIRSA/informe-de-la-cartera-de-proyectos-del-cosiplan-2016.html.

UNDP. (2004). Water governance for poverty reduction key issues and the UNDP response to millenium development goals. New York: Author.

UNESCO-WWAP (2006).Water: A shared responsibility. United Nations World Water Development Report. Paris: UNESCO.

UN-WATER (2008). Transboundary Waters. Sharing Benefits, Sharing Responsibilities. Retrieved from: http://www.unwater.org/downloads/UNW_TRANSBOUNDARY.pdf.

Villar, P. C. (2016). International cooperation on transboundary aquifers in South America and the Guarani Aquifer case. Reviews Bras Polit Int, 59(1), 1-20.

Villar, P. C., \& Ribeiro, W. C. (2011). The agreement on the Guarani Aquifer: A new paradigm for transboundary groundwater management? Water International, 36(5), 646-660.

Vollmer, R., Ardakanian, R., Hare, M., Leentvaar, J., Van Der Schaaf, C., \& Wirkus, L. (2008). Institutional capacity development in transboundary water management. Paris: UNESCO.

Wolf, A. T. (2007). Shared waters: Conflict and cooperation. Annual Review of Environment and Resources, 32, 241-269.

Wolf, A. T., Yoffe, S. B., \& Giordano, M. (2003). International waters: Identifying basins at risk. Water Policy, 5, 29-60.

Woodhouse, P., \& Muller, M. (2017). Water governance-An historical perspective on current debates. World Development, 92, 225-241.

Zeballos, C. (1979). A. El sistema de la Cuenca del Plata: Aspectos institucionales. Integración Lationamericana, 70-87. Retrieved from http://www10.iadb.org/intal/intalcdi/integracion_lati noamericana/documentos/042-Derecho_de_la_Integracion_Estudios_2.pdf.

Zeitoun, M., \& Mirumachi, N. (2008). Transboundary water interaction I: Reconsidering conflict and cooperation. International Environmental Agreements: Political Law Economy, 8, 297-316. 